\title{
Study on Social and Demographic Factors Association with Food Choice in Gujarat
}

\author{
Gautam Parmar $^{*}$, Raju M Rathod ${ }^{2}$ \\ ${ }^{1}$ Assistant Professor, ASPEE Agribusiness Management Institute, Navsari Agricultural University, Navsari \\ ${ }^{2}$ Professor, G.H. Patel Postgraduate Institute of Business Management, Sardar Patel University, Vallabh Vidyanagar
}

\begin{abstract}
Food is an important for human life and source to growth and activities. The food choice and food buying behaviour is complex. There are varieties of factors affects to the food choice such as social, demographic, economic, personal etc. The present study aims to understand the social and demographic association with food choice. To fulfill the objectives descriptive research design was employed and cross sectional data from the Gujarat regions were obtained through questionnaire. The 200 respondents were surveyed and the collected data were analysed with descriptive statistics, independent sample t-test, one way ANOVA. The study found that freshness is most influencing factor followed by price for food choice. There is significant difference found for rural and urban for freshness, availability, occasion, and tradition. The significant difference found for freshness and taste across age groups. For price, freshness, taste and status significant difference were found across education groups.
\end{abstract}

Keywords - Food Choice; Food Preference; Social and Demographic Factors; Association with Food Choice; Factors Affecting Food Choice

\section{Introduction}

Food is essential for everyone's life. Being a basic need of the humankind food and food related purchase decisions are important for marketer. The food choice is regular activity yet there is complex buying behavior observed. It is meaningful in developing country like India where large portion of household income spends on foods. Consumer preference greatly influenced by the factors such as economic, demographic, psychological, sociological, etc. consumer preferences are reflected in terms of product benefit, functions, characteristics and performance criteria.(Rajakumari, 2010). There have been tremendous changes occuring in the pattern of consumers' food choice behaviour, visible in the way they go about food shopping and seeking etery options (Nair, 2014).

The consumption of different food items varies among socio-economic groups and regions (Abha Gupta, 2014). Food choice is a complex process which depends on culture and can be influenced by other factors like personal, social, economic and emotional (Alexandra Bargiota, 2013). Socio-Demographic variables include gender, age, level of education, employment status, profession, marital status, and total number of persons living in the house and living arrangements (S.Koukouli, 2002). The measures of socioeconomic position classify individuals in groups of similar status or prestige, power, knowledge and resources. (Liberatos P, 1988). The present study tries to investigate Social and Demographic factors association with food choice in Gujarat.

\section{Review of Literature}

J De Irala-EsteÂvez, (2000) found positive association between a higher level of education or occupation and a greater consumption of both fruit and vegetables. Education level has an important influence on socioeconomic status. Higher level of education may also increase the ability to obtain or to understand health related information and behaviour. Education needed in develop health promoting behaviour and beliefs.

Jabir Ali, (2010) stated that Indian consumers are still price conservative and adopt "cheap and best" strategy while purchasing a quality product. The preference of the consumers indicates the priority for cleanliness/freshness of food products followed by price, quality, variety, packaging and non-seasonal availability. Further he found that males and females differ significantly on the frequency of purchase and preferred market distance for grocery items and monthly expenditure and preference on packing of vegetables. The age of consumers also plays role in frequency of purchase. The higher income consumer groups purchase fruits and vegetables frequently and also spend higher on them.

Oti, (2018) found that gender did not affect adolescent students perception of the factors influencing their food choice further he added that age does not matter in the discussion of the factors that affect adolescent students food choices. Elena Horska (2011) found that price and quality are important parameters of consumer food choice. 
The food hygiene is also important qualitative factor in food choice; he also added that country's specific habits, traditions influence consumer decision.

\section{Research Methodology}

The present study focuses on the factors affecting food item purchase. To achieve the objectives descriptive research design was employed. The data were collected from the south Gujarat region. The 200 respondents were surveyed by adopting quota sampling technique of nonprobability sampling method. The structured questionnaire was used as research instrument for data collection. The questionnaire was containing questions related to demographic profile of respondents and research questions. The various factors influence food item purchase been identified by reviewing related literatures. These factors were exposed to respondents on five point rating scale based on importance. The collected data were coded and feed in computer software further the data were analyse with the help of computer software. The descriptive statistics, independent sample t-test and one way ANOVA was used to analyse the data.

\section{Data Analysis}

\subsection{Demographic Profile of Respondents}

For present study 200 respondents were surveyed out of 200 respondents, 140 (70 percent) were male and 60 (30 percent) were female. In case of age of respondents it was found that out of 200 respondents 89 (44.5 percent) were below 25 years, 105 (52.5 percent) has age between 26 to 50 years and 6 ( 3 percent) respondents had age between $50-75$ years. In case of education of respondents it was found that out of 200 respondents 66 (33 percent) respondents studied up to post graduate level, 41 (20.5 percent) respondents studied up to SSC/ITI level, 39 (19.5 percent) studied up to under graduate level, 27 (18.5 percent) respondents studied up to HSC/Diploma level and 3 (1.5 percent) were illiterate. In case of occupation it was found that out of 200 respondents 68 (34 percent) respondents were students followed by 61 respondents (30.5 percent) engaged with private job, 42 (31 percent) respondents engaged in business, 17 (8.5 percent) respondents engaged with agriculture and allied activities and 11 (5.5 percent) respondents engaged with government job.

\section{Food choice}

To understand factors affecting food choice 5 point rating scale was used (1-Not important at all, 2-Not Important, 3 - Neutral, 4 - Important, 5- Very Important.
The factors considered were Price, Freshness, Availability, Advertisement, Taste, Season, Status, Neighbour Influence, Occasion, Traditions and Festivals.

Table 1: Factors considered during Food Choice

\begin{tabular}{|l|c|c|c|c|c|c|c|}
\hline $\begin{array}{l}\text { Paramete } \\
\text { rs }\end{array}$ & $\mathbf{1}$ & $\mathbf{2}$ & $\mathbf{3}$ & $\mathbf{4}$ & $\mathbf{5}$ & Mean & $\begin{array}{c}\text { Std. } \\
\text { Deviat } \\
\text { ion }\end{array}$ \\
\hline Price & 8 & 13 & 14 & 57 & 108 & 4.22 & 1.090 \\
\hline Freshness & 2 & 9 & 10 & 78 & 101 & 4.34 & .846 \\
\hline $\begin{array}{l}\text { Availabilit } \\
\text { y }\end{array}$ & 4 & 8 & 42 & 87 & 59 & 3.95 & .920 \\
\hline $\begin{array}{l}\text { Advertise } \\
\text { ments }\end{array}$ & 21 & 38 & 50 & 69 & 22 & 3.17 & 1.172 \\
\hline Taste & 2 & 13 & 28 & 61 & 96 & 4.18 & .971 \\
\hline Season & 4 & 20 & 25 & 79 & 72 & 3.98 & 1.034 \\
\hline Status & 17 & 35 & 58 & 63 & 27 & 3.24 & 1.148 \\
\hline $\begin{array}{l}\text { Neighbor } \\
\text { influence }\end{array}$ & 21 & 44 & 51 & 64 & 20 & 3.09 & 1.166 \\
\hline Occasion & 19 & 24 & 31 & 77 & 49 & 3.57 & 1.246 \\
\hline Traditions & 19 & 24 & 39 & 73 & 45 & 3.51 & 1.232 \\
\hline Festivals & 17 & 18 & 29 & 69 & 67 & 3.76 & 1.246 \\
\hline
\end{tabular}

The above table shows frequency of responses for factors affecting food choice and mean for each factors based on responses. The freshness is the most important factor influencing food choice in study area followed by price, taste, season, availability, festivals, occasions, traditions, status, advertisements and neighbour influence.

\subsection{Independent Sample t-test}

The research try to investigate the differences among rural and urban for food consumption factors and independent sample t-test was employed for the comparison and hypothesis design as under:

Ho: There is no significant difference between rural and urban for factors affecting food choice

$\mathrm{Ha}$ : There is significant difference between rural and urban for factors affecting food choice

Table 2: Comparison between rural and urban for food choice

\begin{tabular}{|c|c|c|c|c|c|c|}
\hline \multicolumn{7}{|c|}{ Independent Samples Test } \\
\hline & & \multicolumn{2}{|c|}{$\begin{array}{l}\text { Levene's Test } \\
\text { for Equality } \\
\text { of Variances }\end{array}$} & \multicolumn{3}{|c|}{$\mathrm{t}$-test for Equality of Means } \\
\hline & & $\mathrm{F}$ & Sig. & $\mathrm{T}$ & $\mathrm{df}$ & $\begin{array}{c}\text { Sig. } \\
(2- \\
\text { tailed } \\
)\end{array}$ \\
\hline Price & $\begin{array}{l}\text { Equal } \\
\text { variances } \\
\text { assumed }\end{array}$ & .003 & .953 & -.326 & 198 & .745 \\
\hline
\end{tabular}




\begin{tabular}{|c|c|c|c|c|c|c|}
\hline & $\begin{array}{l}\text { Equal } \\
\text { variances } \\
\text { not } \\
\text { assumed }\end{array}$ & & & -.327 & 143.370 & .744 \\
\hline \multirow[t]{2}{*}{$\begin{array}{l}\text { Fresh } \\
\text { ness }\end{array}$} & $\begin{array}{l}\text { Equal } \\
\text { variances } \\
\text { assumed }\end{array}$ & 1.333 & .250 & -3.694 & 198 & $\begin{array}{r}.000^{*} \\
*\end{array}$ \\
\hline & $\begin{array}{l}\text { Equal } \\
\text { variances } \\
\text { not } \\
\text { assumed }\end{array}$ & & & -3.340 & 107.072 & .001 \\
\hline \multirow[t]{2}{*}{$\begin{array}{l}\text { Avail } \\
\text { abilit } \\
y\end{array}$} & $\begin{array}{l}\text { Equal } \\
\text { variances } \\
\text { assumed }\end{array}$ & 8.793 & .003 & -2.305 & 198 & $.022 *$ \\
\hline & $\begin{array}{l}\text { Equal } \\
\text { variances } \\
\text { not } \\
\text { assumed }\end{array}$ & & & -2.108 & 110.217 & .037 \\
\hline \multirow[t]{2}{*}{$\begin{array}{l}\text { Adve } \\
\text { rtise } \\
\text { ments }\end{array}$} & $\begin{array}{l}\text { Equal } \\
\text { variances } \\
\text { assumed }\end{array}$ & .002 & .960 & .057 & 198 & .955 \\
\hline & $\begin{array}{l}\text { Equal } \\
\text { variances } \\
\text { not } \\
\text { assumed }\end{array}$ & & & .057 & 140.785 & .955 \\
\hline \multirow[t]{2}{*}{ Taste } & $\begin{array}{l}\text { Equal } \\
\text { variances } \\
\text { assumed }\end{array}$ & .003 & .957 & -1.626 & 198 & .106 \\
\hline & $\begin{array}{l}\text { Equal } \\
\text { variances } \\
\text { not } \\
\text { assumed }\end{array}$ & & & -1.552 & 124.034 & .123 \\
\hline \multirow[t]{2}{*}{$\begin{array}{l}\text { Seaso } \\
\mathrm{n}\end{array}$} & $\begin{array}{l}\text { Equal } \\
\text { variances } \\
\text { assumed }\end{array}$ & .003 & .956 & -1.039 & 198 & .300 \\
\hline & $\begin{array}{l}\text { Equal } \\
\text { variances } \\
\text { not } \\
\text { assumed }\end{array}$ & & & -1.014 & 131.764 & .312 \\
\hline \multirow[t]{2}{*}{$\begin{array}{l}\text { Statu } \\
\mathrm{s}\end{array}$} & $\begin{array}{l}\text { Equal } \\
\text { variances } \\
\text { assumed }\end{array}$ & 2.007 & .158 & .541 & 198 & .589 \\
\hline & $\begin{array}{l}\text { Equal } \\
\text { variances } \\
\text { not } \\
\text { assumed } \\
\end{array}$ & & & .524 & 128.772 & .601 \\
\hline \multirow{2}{*}{$\begin{array}{l}\text { Neig } \\
\text { hbour } \\
\text { influe } \\
\text { nce }\end{array}$} & $\begin{array}{l}\text { Equal } \\
\text { variances } \\
\text { assumed }\end{array}$ & 2.755 & .099 & -1.441 & 198 & .151 \\
\hline & $\begin{array}{l}\text { Equal } \\
\text { variances } \\
\text { not } \\
\text { assumed }\end{array}$ & & & -1.488 & 154.946 & .139 \\
\hline \multirow[t]{2}{*}{$\begin{array}{l}\text { Occa } \\
\text { sion }\end{array}$} & $\begin{array}{l}\text { Equal } \\
\text { variances } \\
\text { assumed }\end{array}$ & 1.129 & .289 & -2.352 & 198 & $.020^{*}$ \\
\hline & $\begin{array}{l}\text { Equal } \\
\text { variances } \\
\text { not } \\
\text { assumed }\end{array}$ & & & -2.324 & 136.633 & .022 \\
\hline $\begin{array}{l}\text { Tradi } \\
\text { tions }\end{array}$ & $\begin{array}{l}\text { Equal } \\
\text { variances } \\
\text { assumed }\end{array}$ & 1.550 & .215 & -2.230 & 198 & $.027 *$ \\
\hline
\end{tabular}

\begin{tabular}{|l|l|l|l|l|r|r|}
\hline & $\begin{array}{l}\text { Equal } \\
\text { variances } \\
\text { not } \\
\text { assumed }\end{array}$ & & & -2.171 & 130.971 & .032 \\
\hline $\begin{array}{l}\text { Festi } \\
\text { vals }\end{array}$ & $\begin{array}{l}\text { Equal } \\
\text { variances } \\
\text { assumed }\end{array}$ & .947 & .332 & -1.776 & 198 & .077 \\
\cline { 2 - 6 } & $\begin{array}{l}\text { Equal } \\
\text { variances } \\
\text { not } \\
\text { assumed }\end{array}$ & & & -1.748 & 135.115 & .083 \\
\hline
\end{tabular}

*Significant at 5 percent level **Significant at 1 percent level

As above table depicts the null hypothesis rejected for the factors freshness at 1 percent significance level and for availability, occasion and tradition at 5 percent significance level. So, it can be infer that there is significant difference found for rural and urban for freshness $(\mathrm{p}=0.000)$, availability $(\mathrm{p}=0.022)$, occasion $(\mathrm{p}=0.20)$, tradition (0.027). There were no significant differences found for price, advertisements, taste, season, social status, neighbour influence and festivals between rural and urban.

\subsection{One Way ANOVA}

An attempt was made to identify, Was there any differences across age groups, education groups and occupation groups for food items choice? The hypothesis designed as follow:

$\mathrm{H}_{1}$ : There is no significant difference for factors affecting food item choice across age groups

H1a: There is significant difference for factors affecting food item choice across age groups

$\mathrm{H} 2_{0}$ : There is no significant difference for factors affecting food choice and education groups

H2a: There is significant difference for factors affecting food choice and education groups

$\mathrm{H}_{3}$ : There is no significant difference for factors affecting food item choice and occupation groups

$\mathrm{H} 3 \mathrm{a}$; There is significant difference for factors affecting food item choice and occupation groups

The results of one way ANOVA for the age groups, education groups and occupation groups shown in below table.

Table-3: One way ANOVA

\begin{tabular}{|l|c|r|r|r|r|r|}
\hline \multirow{2}{*}{$\begin{array}{c}\text { Paramet } \\
\text { ers }\end{array}$} & \multicolumn{2}{|c|}{ Age } & \multicolumn{2}{c|}{ Education } & \multicolumn{2}{c|}{ Occupation } \\
\cline { 2 - 7 } & F & \multicolumn{1}{|c|}{ Sig. } & \multicolumn{1}{c|}{ F } & \multicolumn{1}{c|}{ Sig. } & F & Sig. \\
\hline Price & 2.357 & .097 & 3.416 & $.006^{* * *}$ & 1.555 & .175 \\
\hline Freshness & 3.473 & $.033^{* *}$ & 3.617 & $.004^{* * *}$ & 1.518 & .186 \\
\hline $\begin{array}{l}\text { Availabili } \\
\text { ty }\end{array}$ & 2.145 & .120 & .573 & .720 & 2.082 & $\begin{array}{r}.069 \\
*\end{array}$ \\
\hline
\end{tabular}




\begin{tabular}{|l|r|r|r|r|r|r|}
$\begin{array}{l}\text { Advertise } \\
\text { ments }\end{array}$ & .021 & .979 & 2.110 & .066 & 1.720 & .132 \\
\hline Taste & 3.142 & $.045^{* *}$ & 3.121 & $.010^{* *}$ & .852 & .515 \\
\hline Season & 1.732 & .180 & 1.037 & .397 & .238 & .945 \\
\hline Status & 2.035 & .133 & 3.222 & $.008^{* * *}$ & .572 & .721 \\
\hline $\begin{array}{l}\text { Neighbou } \\
\mathrm{r} \\
\text { influence }\end{array}$ & .906 & .406 & 1.051 & .389 & .852 & .514 \\
\hline Occasion & .438 & .646 & .938 & .458 & .180 & .970 \\
\hline $\begin{array}{l}\text { Tradition } \\
\text { s }\end{array}$ & .554 & .575 & 2.232 & $.053^{*}$ & .342 & .887 \\
\hline Festivals & .376 & .687 & .645 & .665 & .847 & .518 \\
\hline
\end{tabular}

*Significant at $10 \%$ level, **Significant at $5 \%$ level,

***Significant at $1 \%$ level

As above table depicts the differences for factors affecting food item purchase across various groups and it was found that in case of age groups significant differences found for freshness of food products and taste of food products at 5 percent significance level for various age groups where as there were no significant differences found for price, availability, advertisements, season, social status, neighbour influence, occasion, traditions and festivals across age groups. In case of education groups, there were significant differences found for price of products, freshness of products and social status at 1 percent significant level across education groups and there were significant difference found for taste across education groups at 5 percent significance level. Further there was significant difference found for tradition across education groups at 10 percent significance level and there were no significant difference found for availability, advertisements, season, neighbour influence, occasion, and festivals. In case of occupation there were significant difference found for availability as factors affecting food choice across education groups. There were no significant differences found for price, freshness, advertisements, taste, season, social status, neighbour influence, occasion, tradition and festivals across education groups.

\section{Conclusion}

Food buying behaviour is becoming complex with urbanization, convenience and modernization. The present study was conducted to understand the social and demographic factors association for food choice. The study found that freshness is most influencing factor followed by price for food choice. There is significant difference found for rural and urban for freshness, availability, occasion, and tradition. The significant difference found for freshness and taste across age groups. For price, freshness taste and status significant difference were found across education groups. For availability the significant difference was found across occupation groups. The present study will helpful to marketers in segmentation, targeting and position strategies by keeping in mind demographic profile of consumers. It is also further helpful in designing the communication strategies and communicating products to consumers by focusing on freshness, price factors.

\section{Future Research}

The future research can be carried out in detailed segmentation of food items like snaking behaviour, fast food consumption behaviour, eating out behaviour. The comparative studied can also be carried out among age groups (older people and young) for new food trends like foreign foods (e.g pitza, burger etc..) further comparative studied based on education, occupation rural-urban can also be carried out which may help companies in designing marketing strategies playing in this segment.

\section{References}

[1] Abha Gupta, D. K. (2014). Food Consumption Pattern In Rural India: A Regional Perspective. Journal of Economic \& Social Development, Vol. X (1) pp. 1-16.

[2] Alexandra Bargiota, M. D. (2013). Eating habits and factors affecting food choice of adolescents living in rural areas. Hormones , 12(2):246-253

[3] Elena HORSKÁ, J. Ü. (2011). Consumers' food choice and quality perception: Comparative analysis of selected Central European countries. Vol 10 pp.493-499.

[4] Heena Upadhyay, T. P. (2013). Consumer Expenditure Behaviour in India: A case of rural and urban consumer. International Journal of Business and Management Invention, Vol 2(2) pp.68-73.

[5] J De Irala-EsteÂvez, M. G.-G. (2000). A systematic review of socioeconomic differences in food habits in Europe: consumption of fruit and vegetables. European Journal of Clinical Nutrition , Vol.56 pp.706-714.

[6] J.Pollard, S. J. (2002). Factors affecting food choice in relation to fruits and vegetable intake: a review. Nutrition Research Reviews , Vol.15 pp.373-387.

[7] Jabir Ali, S. K. (2010). Buying behaviour of consumers for food products in an emerging economy. British Food Journal, Vol. 112(2) pp.109-124.

[8] Nair, S. .. (2014). Consumer Behavior In Choice Of Food And Branding. 7th Annual EuroMed Conference of the EuroMed Academy of Business (pp. 1160-1169). Norvey: ISBN: 978-9963711-27-7.

[9] Nazrul Islam, G. U. (2010). Factors affecting coonsmers' preferences on fast food items in Bangladesh. The journal of Applied Business Research, Vol. 26(4) pp. 131-146.

[10] Oti, J. A. (2018). Factors Influencing Food Choice: Perception of Public and private Junior High School Adolescent Students in Asiakwa in the Estern Region of Ghana. Journal of Food Nutrition , 02(01) pp.

[11] Rajakumari, D. (2010). Consumer Satisfaction Over Branded And Unbranded Rice In Salem City . Cauvery Research Journal , Vol. 4(1\&2) pp.44-46.

[12] S.Koukouli, I. A. (2002). Socio-Demographic factors and selfreported functional status: the significance of social support. BMC Helath Service Research, Vo.2 pp.1-13.

[13] Thiruselvakumar D., S. K. (2014). Factors affecting food choice and attitude of choosing food items among adolescents in Sounth India. International Journal of Scientific and Research Publications, VOl.4(4) pp 1-3. 